\title{
Increasing public of education awareness about the importance of bringing medical ID cards at healthcare through audiovisual media
}

\author{
Atha Rifqia Pradana ${ }^{1}$, Umi Shalihah ${ }^{2}$, Yudhy Dharmawan ${ }^{3}$, Achmad Zhimawan R. P. ${ }^{4}$, Naufal \\ Ishartono $^{5}$ \\ \{atha.rifqia@gmail.com ${ }^{1}$,ummishalihah98@mail.com ${ }^{2}$,yudhydharmawan@gmail.com ${ }^{3}$, \\ achmdzhimawan@yahoo.com ${ }^{4}$, ni160@ums.ac.id $\left.{ }^{5}\right\}$ \\ 1,2,3 Faculty of Public Health, Diponegoro University, Semarang, Indonesia \\ ${ }^{4}$ SMA Negeri 4 Surakarta, Surakarta, Indonesia \\ ${ }^{5}$ Universitas Muhammadiyah Surakarta, Surakarta, Indonesia
}

\begin{abstract}
A medical ID card is a patient's identity card in a health service which contains patient medical record number. The function of this card is to search medical record documents belonging to patients who have been treated in the health service. As a supporting tool, medical ID card brought by patients is expected to facilitate filling officers to find patient medical record documents so the services can be effective and efficient. One of the inhibiting factors the use of medical ID card is the lack of appeals from registration staff to patients to always carry medical cards. This condition complicates filling officers to retrieve medical record documents according to medical record numbers and the identity of patients who register. For this reason, it is necessary to conduct socialization as an effort to increase public awareness to treat and bring medical cards so there is a continuity of patient health information, which one through the use of an audiovisual media, namely video. Videos are displayed in simple animations with a short duration containing a message about the importance of caring and carrying a medical ID card when seeking treatment. Through socialization in the videos, it is expected that people will be easier to receive and understand the message conveyed so public awareness about the importance of medical cards will increase.
\end{abstract}

Keywords: Medical ID Card, Socialization, Awareness.

\section{Introduction}

According to the World Health Organization (WHO), health is a state of well-being that includes physical, mental, and social conditions which are not only free from illness or disability [1]. In the globalization era, health is the main factor that must be met by the majority of population with the aim of having a long life expectancy. Thus, the higher the health needs of each individual, it will affect the activities in health care facilities. Crowded patient visits will affect the service concerning effective and efficient, both for patients and health care facilities [2], [3].

A registration system is the first service given to patients by health care. The process of patient registration services in health care is influenced by three factors, namely human resources, facilities and infrastructures, and Standard Operating Procedure (SOP) [4]. Services provided at the registration, when the patient is coming the first time to the hospital is supported by facilities and infrastructure, one of them is a medical ID card. Each patient has a medical ID card as an identity card in a health service. Through this card, medical record documents of patients who have already been treated at the healthcare can be searched because there is a 
patient medical record number in the medical ID card [5]-[7]. A medical ID card is a tool for registration staff to provide medical record files and facilitate patient registration during treatment [5]. Patients who bring medical ID card when they come to health care will make registration staff to look for medical record documents easier [6], [8].

The length of time used by filling officers to search for medical record file causes many older patients to choose not to bring the medical ID card. They will claim to be new patients to accelerate health services [9]. The calculation time of providing a medical record file begins when the patient arrives until the patient registers. One obstacle that inhibits the provision of medical record files is misfiled or misplacement in some files so officers need longer time to look for medical record documents until they are found [5].

Accurate health information is important for individuals and communities, so they can make decisions regarding their health [10], [11]. The importance of carrying medical ID cards results in obtaining ongoing care and treatment in accordance with availability for medical record files [7]. According to the previous study, providing easy-to-understand information will make the community as users of health services easier to receive information that delivered so there is no misperception [10].

Low public awareness in carrying medical ID card needs to be overcome to provide a patient's medical record that is sustainable in health care [5]. Socialization of using a medical ID card value is a method implemented to increase public awareness about the importance of carrying this card during treatment. These socialization aims are to improve the health services provided to patients based on regulations [3], [5].

Video is an audiovisual media that can be used to increase community awareness to bring medical ID card when visiting health care. Based on previous studies, media is an important part of the development of identity so information that delivered can be accepted easily [12], [13]. This video is playing in the waiting room area before patients receive services. It is because this place is always crowded with people as users of health care.

\section{Literature Review}

A medical ID card is an identity card that is owned by a patient in health care. The compliance of officers in asking medical ID card can accelerate the queue so it can increase patient satisfaction. This identity card function is to search for medical record documents belonging to patients who have already been treated at the health care. The arrival of the patient to health care that bringing a medical ID card will speed up the registration officer to look for the patient's medical record documents so there are expectacions to avoid excessive patient accumulation [10].

Patients who come to health care institutions that bring a medical ID card will personify ongoing patient health information. That is because, in a medical ID card, listed the patient's medical record number which aims to facilitate the search for the patient's identity by registration staff in the registration unit. Registration staff will submit the patient's medical record number to the filling officer then to retrieve the patient's medical record file. Therefore, the medical ID card will make officer filling easier in finding medical record documents because of the availability of medical record numbers [4], [7].

The medical record is an important database that is used as a basis or guideline in providing services and treatments to patients. There are two forms of recording medical records, manual and digital, with their respective strengths and weaknesses [14]. Consistency of medical 
record reporting will make doctors, nurses, and other healths personnel easier to monitor the health and do treatment for patients. Based on accurate medical record which includes health status and a history of care and treatment of patients, treatment of patients in a health care can be done comprehensively [15].

According to PERMENKES (Peraturan Menteri Kesehatan) Nomor 269 /MENKES/PER/III/2008, medical records are files that contain notes and documents, including patient identity, checkup results, notes of treatment that has been given, and other actions and services that have been given to the patient. Medical records contain accurate health information so it can be used by doctors, nurses, and other health workers as a guiding basis for taking medical treatment of patient. Patients have the right to determine who knows their health records [15], [16].

Public awareness in carrying medical ID cards can be improved in several ways. In simple terms, changing activities with community goals is done through changing knowledge and attitudes in a better direction. This study relates to the awareness of carrying medical ID cards, so the changes in community activities are carried out through learning and teaching events called learning [17].

Learning can be delivered through socialization with the community as the object [12], [13]. Socialization is held with the aim of several things, namely [13]:

1) To produce basic and applied knowledge intensively.

2) To change a part of knowledge that needed effectively.

3) To create humanity and value of the provisions governing innovation.

In line with the development of technology, the process of delivering learning can be done easily by using media in the learning process. Media functions are to distribute information from the giver of the message to the recipient of the message, both soft file or hard file. The use of media is considered to help learning in this study because the information delivered can be understood by the community easier. If this condition is realized, there will be a behavior change of the community in bringing medical ID cards when they need treatment at a health care [18]. This medical ID cards could be one of the learnings facilities. In particular, earning facilities gave any contribution to learning outcomes indirectly [19].

One of the uses of the media to communicate learning is through audiovisual media. Audiovisual media is defined as a communication media that combine several elements of text, sound, graphics, images, photographs, animation, and moving videos. Based on previous studies, audio-visual media is effective for describing the content and encouraging reflection on people who see and hear audiovisuals. This creates a reflection in a positive attitude in a sustainable manner [11], [18]. In this study, reflection is an increase in public awareness in carrying medical ID cards. The advantages of using audiovisual media, namely: 1) enriching and improving learning methods; 2) expanding the implementation of education; and 3) reducing funding for learning media because of the use of technology [20].

Audiovisual media that use video can describe a process. In this study, the video will show the process of why a medical ID card needs to be taken by patients every time they seek treatment at health care. A medical ID card that is carried by patients when seeking treatment at a health care will actualize the ongoing patient health information in accordance with the medical history listed. In addition, videos can also describe a theory through colored animation where the representation of video is 3-dimensional (3D).

Some weaknesses can be found from the use of audiovisual media. Videos that are played too fast will cause the patient as the video audience to have difficulty in following well-played videos. This is because video shows that have been played through are difficult to playback, 
unless video playback is done in entirety. To produce video in good quality, high costs are required in proces video making and tool maintenance [18].

An object of the video to increase public awareness in bringing medical ID card is patients and visitors in health care. Videos are displayed on a television screen in the patient's waiting room. Background of the selection of targets and place where the video shows are because the waiting room is one of the places in the health care that is always crowded with patients and visitors. With the condition of the waiting room that always crowded, it is expected that the video playback carried out is more effective, efficient and comprehensive [18], [20].

The expected outcome of the video playback is the increasing public awareness of bringing medical ID cards when they need treatment at health care. With the appearance of awareness of bringing medical ID card, people have realized the importance of health information in sustainable medical record.

\section{Approach}

This study uses an approach through a literature review. Keyword in article search, namely: "Medical ID card", "Educational Video", "Audiovisual Media", "Medical Record Document", "Waiting Time of Service" and "Quality of Health Service". Search results of keywords found several articles. Articles were pre-selected based on the results of the research conducted and adapted to the topics raised by the author. Approach method used for the literature review is shown in Figure 1.

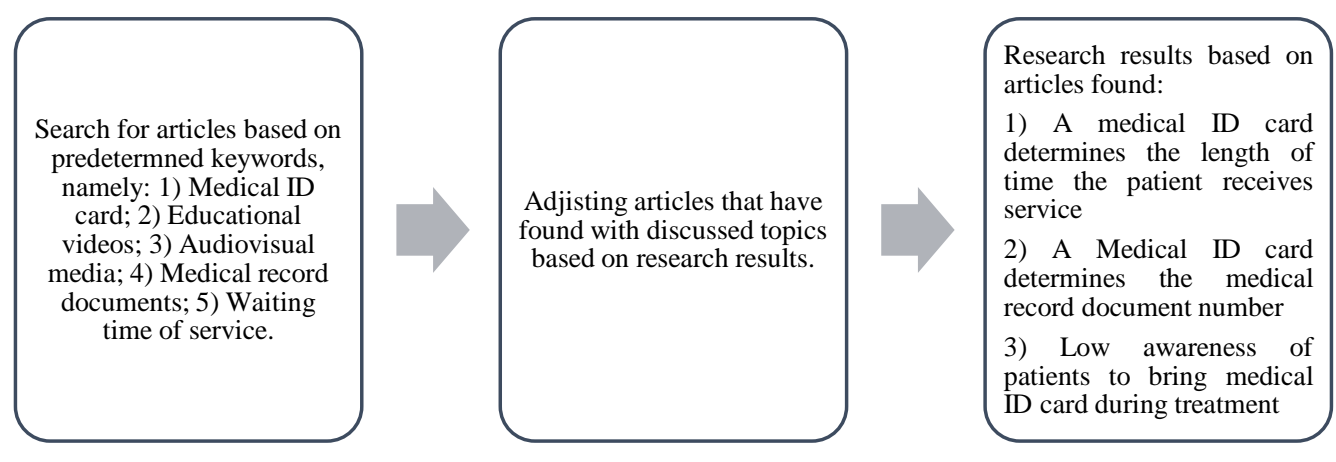

Fig 1. Summary of the literature review process

\section{Findings And Result}

One of the quality services in health care facilities that need to be improved is at the patient registration unit [9]. The registration unit is the main place that patients visit when patients seek treatment at health service [4], [10]. The registration unit has a function or role as the service provider who is first received by the patient or family. Good or bad quality of service will be assessed at the place of patient acceptance [4], [5], [8], [9]. Thus, the patient at the registration unit will spearhead the service of a health facility [8]. 
The patient's identity in a health care facility is characterized by ownership of the medical ID card to search patients' medical record documents [4]. Use of medical ID card at the time of treatment is very important for the registration officer to provide the patient's medical record file [5], [7]. If the patient does not bring the medical ID card, provision of the medical record file will also be longer, so the services provided by the doctor to the patient become obstructed [7]. The more patients who do not carry a medical ID card, the longer the registration staff will be in providing medical records. The faster the provision of medical record documents to the polyclinic, the faster the services provided to patients [5], [7].

In providing services on the registration unit, officers often find difficult to give service to patients who do not carry medical ID cards [7]. This is due to the length of time used by registration officers to find medical record numbers in the register book and computer. Based on Keputusan Menteri Kesehatan Nomor 129 Tahun 2008 concerning Standar Pelayanan Minimal (SPM), standards for the provision of the outpatient medical record files is 10 minutes, and the service of medical records for inpatients is 15 minutes [5].

At the patient admission unit, patient will do patient's the admission process by registering as one of the patients [21]. There are two types of patients, old patients and new patients. Old patients are patients who have already been treated, so they can immediately register and new patients are patients who are first treated and must register as new patients to make a medical ID card [21], [22]. It because patients who seek treatment must have a medical card [22]. Registration officer will carry out an identification process for collecting patient identity data. This will be done either for new patients or old patients. The list of patient registrations is given by the admin to the Medical Record (MR) officer, then the MR officer looks for the patient's medical record document.

If medical record document of patient is exists, the medical record officer submits the patient's medical record document to the nurse. But if patient's identity is not found, the officer will make a new medical ID card so patient will be considered a new patient. Flow of the utilization of patient medical ID card will be explained in Figure 2.

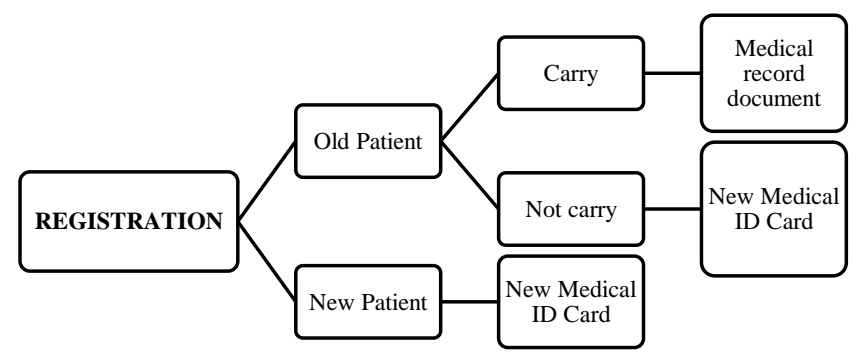

Fig. 2. Patient medical ID card ownership

This can be detrimental to patients and health care facilities. The disadvantage for the patient is the examining doctor does not know the patient's disease history so it must be reexamined and hampered the services to be provided by health workers. The disadvantages for health care facilities are patients with one name can have more than one number so it can increasing the number of stored medical records [3], [5], [7], [21], [22]. 
According to a review of previous studies, awareness of patients, especially old patients in carrying medical ID card when returning to health care facilities is still lacking [23]. Therefore, one method that can be used to discipline patients in bringing medical ID card when they seek treatment is through the playing of educational videos. This videos about the importance of bringing medical ID card at health care providers when they seek treatment. By showing educational videos, people can learn through events that seem to be experienced by themselves. This causes memories of the material delivered through educational video bto ecome easy to remember. In addition, videos are effective to be used as a learning media in mass, individuals, and groups [24].

Video media was selected as a learning media developed because video media was relatively easier to operate [25]. Video is one type of audiovisual learning media that stimulates the functioning of sense of hearing and sense of sight [24]. As an audiovisual media, video can display sound, images, and motion at once. Video ability to visualize material, effective to help convey material that is dynamic.

Public awareness of education is an important aspect in building the character of a nation [25], [26]. The use of educational videos as a learning media is able to provide clarity of messages because people see objects to learn in concrete ways. In addition, the use of video educational media can increase motivation and retention (memory and absorption). Video media is an interesting media for counseling because displays of audiovisual and images are one of the preferred methods in communication, both for men and women and also for people who are low and high educated [13], [24]. Introduction appearance of the video in this study is illustrated in Figure 3.

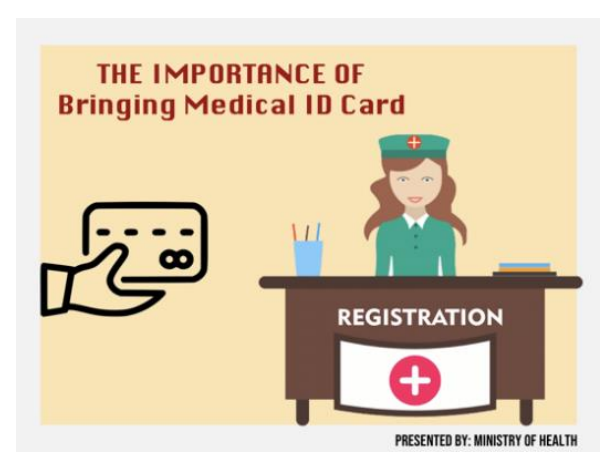

Fig. 3. Display of the introduction video

The content contained in the video is introduction, function of medical ID card, importance of bringing medical ID card when seek a treatment, relation between medical ID card and medical record documents, and relation between patient satisfaction and health care workers. These video contents are packaged in a 1,5-minutes video and played at waiting room in registration unit of health service facilities. Time allocation for each content is explained in Table 1.

Table 1. Time allocation for content in video

\begin{tabular}{clc}
\hline Number & \multicolumn{1}{c}{ Video Content } & Duration (Seconds) \\
\hline 1. & Introduction & 5 \\
2. & Function of Medical ID card & 10 \\
3. & Importance of carrying medical ID card when seeking & 30 \\
& treatment & 30 \\
\hline
\end{tabular}




\begin{tabular}{lll}
\hline 5. & $\begin{array}{l}\text { Relation between medical ID card and medical record } \\
\text { documents } \\
\text { Relation between patient satisfaction and health care }\end{array}$ \\
\hline \multicolumn{2}{c}{ Total Video Duration } & 15 \\
\hline
\end{tabular}

Contents that contained in the video, namely:

1. Introduction

In this section, definitions and a brief description of medical ID card with 5 seconds duration will be displayed. Introduction in the video is a simple animation (illustration).

2. The Function of Medical ID card

The next video content explains about medical ID card function, namely:

- Continuous patient health history.

- Make health workers easy to take medical treatment

- Avoiding redundancy of medical record documents.

- Increase efficiency and effectiveness that have an impact on service quality.

The four medical ID card functions are displayed in the video in the form of writing points with simple animation that will appear one by one. Duration of the content on medical ID card function is 10 seconds.

3. Importance of carrying medical ID card when seeking treatment

Videos about this content are allocated for 30 seconds. Video footage is shown in a simple illustration of why patients need to bring medical ID card when seeking treatment at health care facilities. In addition, it also shows what effects can be caused if the patient does not bring the medical ID card. Thus, it is expected that public awareness in carrying out medical ID card will increase due to understanding the use of medical ID card.

4. The Relation between medical ID card and medical record documents

Through the utilization of medical ID card, patient's medical record document at a health care facilities can be sustainable. The duration of this content is 30 seconds through video illustrations concerning the description of how a continuous medical record document.

5. The Relation between patient satisfaction and health care

The use of medical ID card will increase the effectiveness and efficiency of healthcare facilities officers in serving patients. This condition will impact patients satisfaction because they do not need to take a long time to wait for treatment services. Duration of this content is 15 seconds through a video illustration of how the response and impact that felt by patients when carrying medical ID card during treatment.

Through this educational video, it is expected that there will be an increase in patient awareness about the importance of bringing medical ID card when seeking treatment, especially for old patients. Thus, the patient's medical history listed on the medical record document can be sustainable and can facilitate health workers in doing the medical treatment. In addition, patients who are disciplined to bring medical ID card can avoid the redundancy of medical record documents and improve quality of service. 


\section{CONCLUSION}

The patient who wants to seek treatment must have a medical ID card, both new and old patients. A medical ID card can facilitate registration officers in finding patient medical record documents so it can speed up the service. In addition, with the medical ID card, patient's medical history from the first to the last treatment can be recorded in the medical record so that doctors and medical personnel can provide treatment quickly and precisely. However, there are still many patients who are not aware of the importance of bringing medical ID card during treatment. Thus, need an education that can increase patient awareness. One of educational method that can be applied is through audiovisual, namely video media. The use of educational videos can clarify the message to be conveyed and be more memorable so can be easily accepted by all persons.

\section{References}

[1] World Health Organization, "Public health: Innovation and intellectual property rights," 2006.

[2] V. Schoeb, "Healthcare service in Hong Kong and its challenges," China Perspect., vol. 2016, no. 4, pp. 5159, 2016.

[3] L. Zucco, G. Desmond, and B. Carpenter, "Identity cards help patients identify their doctors," BMJ Qual. Improv. Reports, vol. 2, no. 2, pp. 1-3, 2014

[4] N. B. Shofiana, S. P. Arso, and E. Y. Fatmasari, "Analisis proses pelayanan pendaftaran pasien di Puskesmas Jatisrono 1 Kabupaten Wonogiri,” J. Kesehat. Masy., vol. 7, no. 1, pp. 105-112, 2019.

[5] D. N. Haviva, Rumpiati, and D. Nurjayanti, "Penggunaan Kartu Identitas Berobat (KIB) dalam penyediaan berkas rekam medis pasien rawat jalan di UPT Puskesmas Siman Kabupaten Ponorogo," Glob. Heal. Sci. vol. 3, no. 3, pp. 245-251, 2018.

[6] F. Verbeke, G. Karara, S. Van Bastelaere, and M. Nyssen, "Patient identification and hospital information management systems in sub-Saharan Africa: a field study in Rwanda and Burundi," Rwanda Med. J., vol. 69, no. 4 , pp. $7-12,2010$.

[7] A. Widiarta, B. Hendro, and R. Asuti, "Tinjauan penggunaan kartu identitas berobat dan lama waktu penyediaan dokumen rekam medis pasien rawat jalan lama di RSUD H. Damanhuri Barabai tahun 2013," Jurkessia, vol. 5, no. 1, pp. 45-49, 2014.

[8] G. B. Kuntoadi and R. Adiprana, "Tinjauan lama waktu tunggu pendaftaran di tempat penerimaan pasien Rumah Sakit Kepolisian Pusat RS Sukanto,” Medicordhif, vol. 4, pp. 39-43, 2017.

[9] I. S. Tena, "Faktor penyebab lama waktu tunggu di bagian pelayanan rekam medis rawat jalan RSUD Panembahan Senopati Bantul," 2017.

[10] I. K. Wardani, M. K. Koeswo, and T. W. Sarwiyata, "Efektivitas pelatihan komunikasi terhadap kepuasan pasien pada petugas informasi dan pendaftaran rumah sakit," Profesi (Profesional Islam. Media Publ. Penelit., vol. 15 , no. 2 , p. 71,2018

[11] H. Payne, V. Arredondo, J. H. West, B. Neiger, and C. Hall, "Use and acceptance of social media among community health workers," J. Community Med. Health Educ., vol. 5, no. 3, pp. 1-6, 2015.

[12] S. Genner and S. Daniel, "Socialization as media effect," Roessier, vol. 1, pp. 1-16, 2016.

[13] A. O. Karpov, "Socialization for the knowledge society," Int. J. Environ. Sci. Educ., vol. 11, no. 10, pp. 34873496, 2016

[14] J. S. Wald et al., "A patient-controlled journal for an electronic medical record: Issues and challenges.," Stud. Health Technol. Inform., vol. 107, no. Pt 2, pp. 1166-70, 2004.

[15] M. Marinic, “The importance of health records," Sci. Res. Publ., vol. 7, pp. 617-624, 2015.

[16] E. Ngo, N. Patel, K. Chandrasekaran, A. J. Tajik, and T. E. Paterick, "The importance of medical record: A critical professional responsibility," Medical Practice Management, pp. 305-309, 2016.

[17] F. H. R. Francea, E. De Clercqb, and M. Bangelsc, "Purposes of health identification cards in Belgium," Stud. Health Technol. Inform., vol. 116, no. February 2005, pp. 415-420, 2005.

[18] A. Fujiyanto, A. K. Jayadinata, and D. Kurnia, "The use of audio visual media to improve student learning outcomes in material relationships between living creatures," J. Pena Ilm., vol. 1, no. 1, pp. 841-850, 2016.

[19] A. R. Firdausy, N. Setyaningsih, L. S. Ishabu, and M. Waluyo, "The Contribution of Student Activity and Learning Facilities to Learning Independency and its Impact on Mathematics Learning Outcomes in Junior High School," IJOLAE Indones. J. Learn. Adv. Educ., vol. 1, no. 2, pp. 29-37, 2019. 
[20] A. S. J. Al-Khayyat, "The impact of Audio-Visual Aids (AVA) and Computerize Materials (CM) on University ESP students' progress in english language," Int. J. Educ. Res., vol. 4, no. 1, pp. 273-282, 2016.

[21] L. Lathifah, "Kajian efektivitas Kartu Identitas Berobat (KIB) di Puskesmas Mlati I Sleman Yogyakarta," 2017.

[22] Y. Indrawati, Sulistiowati, and J. Lemantara, "Rancang bangun aplikasi pencatatan rekam medis pada unit rawat jalan di Rumah Sakit Assakinah Medika Sidoarjo," JSIKA, vol. 4, no. 2, pp. 1-6, 2015.

[23] G. B. Kuntoadi and R. Adipana, "Tinjauan Lama Waktu Tunggu Pendaftaran Di Tempat Penerimaan Pasien Rumah Sakit Kepolisian Pusat R.S. Sukanto,” vol. 4, pp. 39-43, 2017.

[24] S. Hadi, "Efektivitas penggunaan video sebagai media pembelajaran untuk siswa sekolah dasar," in TED\&PDs, 2017, pp. 96-102.

[25] M. A. Fauzan and D. Rahdiyanta, "Pengembangan media pembelajaran berbasis video pada teori pemesinan Frais," J. Din. Vokasional Tek. Mesin, vol. 2, no. 2, p. 82, 2017. 